\title{
De store Landboreformer i Sønderjylland.
}

(Foredrag, holdt ved Dansk historisk Fællesforenings Aarsmode

1 Aabenraa den 19. Maj 1939.)

Af Holger Hjelholt.

Den tyske Forfatter Ernst W i e chert skrev for et Par Aar siden en ualmindelig smuk Bog af selvbiografisk Art: Wälder und M'enschen. Eine Jugend, og der er i den en enkelt Betragtning, som jeg geme vil have Lov at bruge som Indledning til det efterfølgende. Som en Mand vel omkring de halvthundrede ser Wiechert tilbage over de svundne Aar, ser sig som ved den ene Ende af en lang, lang Vej, der strækker sig mellem dunkle Krat og indtil Jordens Ende. Og der langt jorte i Baggrunden ser han sig selv staaende som en lille Dreng, barfodet, med Hyrdestav i Haanden, en Dreng, der drager ud med sin Hjord for at erobre sin Verden. Og det, som man ellers ikke til daglig har fremme i Bevidstheden, staar pludselig klart for ham: den uhyre Afstand, der skiller én fra sin Begyndelse.

Som en Mand omkring de halvthundrede ved at se tilbage over sin Udvikling oplever Fornemmelsen af Perspektiv og Afstand, saadan gør Historikeren det ved sin Fordybelse i fremfarne Tiders Begivenheder og Sanfundstilstande. Da vi i Fjor mindedes de tre Gange halvthundrede Aar, der var forløbne siden Stavnsbaandets Ophævelse i Kongeriget, og mange Historikere og Jubilæumsskribenter greb Pennen for $\mathrm{i}$ Artikler og mere eller mindre indgaaende Undersegelser at tegne et Billede af de store Landboreformers Tidsalder, da fæstedes Blikket stærkt ved den uhyre Afstand, der skiller Nutidens Landbrug fra Datidens, Nutidens Bonde fra det 18. Aarhundredes stavnsbundne Hovbonde. Der var, som vi erindrer, ganske vist de Folk, der i Stedet for at dvæle ved Udviklingen og Fremskridtene søgte at trække Paralleller mellem Nutid og Datid og mente, at Bondestandens nuværende Tynge og Hov- 
bondens Aag vel saadan omtrentlig kunde veje lige meget, og der var historisk-politiske Roster, der med Plougs Ord fra Festen 1888 med Føje spurgte: "Tør vi prise Bernstorffs Eftermæle - uden i hans Aand at handle selv?" Det store og blivende Indtryk ved Fordybelsen i Datidens Samfundsforhold var dog Afstanden mellem da og nu.

Som vi ved, udgør Forordningen af 20. Juni $1,788 \mathrm{kun}$ en enkelt af de mange Forordninger, hvoraf Reformtiden prægedes, alligevel betydningsfuld nok til, at vi i Kongeriget lader 1788 være Mindeaaret for de store Landboreformer. I S ø n d e rjy 11 a nd derimod er det, som jeg skal vise, vanskeligere at knytte Mindet om Reformerne til et enkelt Aar. Nok kom Vaarens Budskab i 1788 saa tidligt til Landet som sjældent før eller efter - allerede den 13. April sprang det gamle Bøgetræ i Augustenborg Slotspark ud $\mathrm{d}^{1}$ - men den tidlige Vaar indvarslede ikke i Sønderjylland nogen Frihedsreform saadan som Stavnsbaandsløsningen i Kongeriget. De Baand, der snærede Dele af den slesvigske Bondestand, Livegenskabet, lostes lidt efter lidt i Aarhundredets sidste Aartier paa de fleste Godser, og lovformeligt og endeligt afskaffedes Livegenskabet først ved en Forordning fra 1804. Og noget rigtigt Holdepunkt for at vælge et bestemt Mindeaar giver heller ikke de andre vigtige Landboreformer - om Udskiftningen kom f. Eks. to betydningsfulde Forordninger med nogle Aars Mellemrum. V'i maa da holde os til, at det er Tiaarene væsentlig efter Christian VII.s Regeringstiltrædelse, som vi mindes som den store Landboreformtid i Sønderjylland.

Fra slesvig-holstensk Side fremhæves ofte og ikke uden Berettigelse de mange fælles Baand mellem det danske Hertugdømme Slesvig og det tyske Hertugdømme Holsten. Ogsaa Livegenskabets snærende Baand var delvis fælles, idet Livegenskabet fra Holsten havde bredt sig til Sydslesvig og forskellige angelske Godser. Men det maa iøvrigt siges, at en Sysselsættel-

1) Sønderj. Aarb. 1929. S. 107. 
se med Landboreformernes Lovgivning giver et stærkt Indtryk af et $\mathrm{S}, \mathrm{v} æ \mathrm{lg}$ mellem Slesvig og Holsten og viser, hvor inderligt den sønderjydske Bondestand, Landets Marv, ved den gældende Jydske Lovs Bestemmelser knyttedes til det egentlige Danmark. Trods det administrative Fællesskab i Hertugdømmernes øverste Styrelse - i det saakaldte Tyske Kancelli og i Rentekammerets tyske Kammerkancelli - kunde der helier ikke blive Tale om fælles Forordninger paa Landbolovgivningens Omraade. I Holsten fandtes f. Eks. hverken Ornum eller Kirkestuf eller gjaldt Jydske Lovs Regler om Reb og Maal.

En Foranstaltning, der udførtes i Aarhundredets fire sidste Aartier, og som for den slesvigske Bondestand blev af stor Betydning, var i sit Udspring egentlig ikke af reformatorisk Art. Jeg tænker paa den omfattende Af $\mathrm{h}$ æ $\mathrm{n}$ dels e og Udstykn ing af K rongodset, der fandt Sted, og til hvilken Plan den danske Stats Finansnød, fremkaldt ved de store Rustninger under Krisen 1762, havde givet Stødet. Det var saa vist ikke en Plan, som Konseillets Medlemmer foreslog Kongen med Glæde. I deres Forestilling fra Begyndelsen af Aaret 1764 udtalte de tværtimod, at de vilde have prist, sig lykkelige, om de kun havde maattet sysselsætte sig med nye Erhvervelser, og at de vilde ønske og haabe paa, at den Dag maatte komme, da Gælden var ude af Verden, og da Staten atter vilde blive i Stand til at anbringe Penge i Jordegods! $\left.!^{1}\right)$ Men Nødvendigheden krævede, at den bitre Pille blev slugt, og da først dette var sket, var det andre Ræsonnementer, der fremførtes: at det var mere fordelagtigt, at Jorden var i Privateje end i Statens Eje, at en Udstykning af Godserne skaffede Plads til flere Familier og saaledes fremmede Befolkningsforøgelsen, og at mindre Ejendomme plejede at blive bedre dyrkede end store. Hvor udmærkede disse Grunde end maatte være, og hvor stor Vægt man end i Regeringskredse maa have lagt paa dem, saa maa det dog betones,

1) Rentekammerets tyske Forestill. 1764 7/2 (Nr. 108). (Rigsarkivet). 
at Synspunktet om ved Bortsalget at skaffe Staten Penge og ogede Indtægter aldrig tabtes af Syne.

Ved Afhændelsen af Krongodserne blev det nu af største Betydning, at Domænegaardene ikke solgtes samlede til de højestbydende - noget, Kammeret for Resten først havde prøvet paa - men at de deltes i mindre Parceller, der bortsolgtes paa nærmere fastsatte Vilkaar. Der fandt altsaa en udstrakt Udstykning Sted - en Fremgangsmaade, der jo virker helt nutidigt. Om Vilkaarene for Salgene i de første Aar - 1765 til 1768 - skal jeg anføre, at Parcellerne solgtes til evig Arv og Ejendom, og at der ikke skulde udbetales nogen Købesum, men at der vilde være at svare en aarlig uafløselig Afgift, Kanon, til Kronen. Størrelsen af denne var det, som var Genstand for Opbuddet ved Parcellernes Bortsalg. Ved Udparcelleringen bestemtes det, at der skulde sørges for, at ogsaa Kaadnere og Inderster fik overladt nogen Jord mod en nærmere fastsat Afgift. Ved Domænegaardenes Nedlæggelse bortfaldt jo Hoveriydelserne fra Bønderne, og der fastsattes en Pengeafgift, som disse havde at svare i Stedet.

I Midten af Maj 1768 foregik Oprettelsen af Generallandvæsenskollegiet $i$ København og af den slesvig-holstenske Landk o m mis si o n paa Gottorp med det Formaal at fremme Reformer i Landbruget, denne "Hovedkilde.til en Stats Flor og Velstand«. Generallandvæsenskollegiet gik ganske vist allerede ind i 1773, og dets Forretninger henlagdes atter under Rentekammeret, men Landkommissionen kom til at bestaa til et godt Stykke ind i det 19. Aarhundrede, og dens Virksomhed fik en overordentlig Betydning for Landboforholdene i Slesvig. Der udstedtes for den en Instruks, bestaaende af ikke mindre end 18 Paragraffer og indeholdende et meget omfattende Arbejdsprogram. Blandt de Opgaver, som den havde at løse, var ogsaa den fortsatte Udparcellering og Afhændelse af Domænegodset.

De Vilkaar, paa hvilke Parcellerne bortsolgtes af Landkommissionen, kom imidlertid til paa et væsentligt Punkt at ad- 
skille sig fra de Betingelser, der hidtil var brugt ved Bortsalgene. Ved de hidtidige Salg havde det som sagt været den aarligt svarende Kanon, der havde været Genstand for Opbuddet, og den Menneskene iboende Letsindighed havde givet sig grelle Udslag ved at drive Kanon op i en Højde, som det i Længden var Parcellisterne ganske ugørligt at udrede. Rentekammerets njeblikkelige Glæde over de indbringende Salg havde saaledes al Udsigt til at afløses af sørgelige Skuffelser, hvad ogsaa blev Tilfældet. Men ved de af Landkommissionen foretagne Bortsalg gik man over til at fastsæotte en bestemt Kanon, svarende til, hvad man mente, Parcellerne var i Stand til at bære, og hvad der blev gjort til Genstand for Auktion, var en Købesum, som Køberen desuden vilde have at udrede ved Overtagelsen. Trods Auktioners Indflydelse paa den menneskelige Lidenskab turde det dog vel forventes, at en Køber kunde skønne over, on den budte Sum og hans okonomiske Evne stod i et nogenledes rimeligt Forhold til hinandell.

I Udparcelleringen af Domæner indtraadte der i 1784 en Pavse, idet Landkommissionen havde faaet saa mange Hverv overdraget, at det fandtes formaalstjenligt, at Udparcelleringen for en Tid stilledes i Bero. Man skønnede ogsaa, at Jordhungeren da var ved at være mættet, og de lysthavendes Antal dalende, saa fortsatte Nedlæggelser vilde være mindre fordelagtige for Kronen. Efter nogle Aar optoges Udparcelleringen dog igen og blev ved til Slutningen af Aarhundredet, da man havde solgt alle de Domæner, som man ved Landkommissionens Nedrettelse i 1768 havde trenkt paa at sælge. Det er altsaa ikke rigtigt, naar II a x S e ring i sit store Værk fra 1908 om Erbrecht und Agrarverfassung in Schleswig-Holstein taler om Tidsrummet 1765 til 1786 som det, i hvilket Domænerne nedlagdes. Misforstaaelsen skyldes sikkert det Skrift om Domænernes Nedlæeggelse, som den Deputerede i Rentekammeret H. Ka m p h ö ven er i 1787 udgav, men i Skriftets Titel hedder det dog udtrykkeligt, at det er en "Beschreibung der bereits vollführten Nie- 
derlegungen«, en Beskrivelse af de a $1 \mathrm{l} \in \mathrm{r}$ e d e udførte Nedlæggelser.

Kamphöveners Skrift 'var et, dog ikke ensidigt, Forsvar for Domænernes Nedlæggelse, og han gjorde udførligt rede for de betydelige Fordele, som han mente var forbundet dermed. At Staten vandt adskilligt øgede Indtægter, var uimodsigeligt, men det svage Punkt her var unægtelig, at Pengenes Værdi er saa skiftende. Herfor havde Kamphövener ogsaa Blik, da han egentlig helst havde set Kanon fastsat i "Naturalier", der saa kunde omregnes efter de til enhver Tid gældende Priser. En anden stor Fordel - af social Art - var den talrige Rakke nye Landbrug, som Domænernes Udstykning skabte. At denne Udstykning i mindre Brug ogsaa vilde oge Landets Produktion som Helhed, følte Kamphövener sig - og med Rette - overtydet om, selv om Herregaardssmørret jo endnu længe skulde beholde Fortrinet frem for Bondesmørret. I Løjt, udtalte Kamphövener dog, var der mange Bønder, der lavede lige saa godt Smor som paa adskillige store Gaarde.

Ved Domænernes Nedlæggelse afløstes som sagt Hoveriydelserne til disse, og der fandt endvidere en delvis Overgang til Selvejendom Sted. Ogt endelig afskaffedes L ive e nskabet paa den eneste Domæne i Slesvig, hvor det bestod, nemlig Lindau i Nærheden af Ekernforde. Paa de holstenske Domæner, hvor Livegenskabet raadede, ophørte det ligeledes ved disses Bortsalg.

Den personlige Ufrihedstilstand, som Livegenskabet betøxd, maatte naturligt i Oplysningens Tidsalker virke som en Skamplet paa Tiden, en Skamplet, som det gjaldt om snarest gorligt at faa aftvættet. Man havde ikke kunnet unlkaa, skrov ell af Reformvennerne, C. H. von Eggers, en af A. P. Bernstorffs Medarbejdere, at faa Øjnene op for Livegenskabet Fædsler, da »den humanere Statsfilosofis Grundsætninger «, efter at Rousseau havde foretaget sine Undersøgelser, udbredtes i Norden. ${ }^{1}$ ) Og en anden af Oplysningstidens kendte Skri-

1) Det skandinaviske Litteraturselskabs Skrifter. 1805 . I. S. $495 \mathrm{f}$. 
benter, A u gust Hennings, en Mand, der stod Ernst Schimmelmann nær, udtalte i et Skrift fra 1785: "Fornuftige Statsmænd nægter ikke længere, at man ikke kan tænke paa at faa Velstand $i$ et Land, saa længe der endnu findes Spor af Livegenskab. Den, der gør sig rigtige Begreber om Moralen, vil ligeledes indse det uforsvarlige, der for Gud og Mennesker ligger i Livegenskabet. (1) $^{1}$

Ved Afskaffelsen af Livegenskabet paa Domænerne var Staten gaaet i Spidsen med et godt Eksempel, og at man i Regeringskredse onskede, at de private Godsejere vilde følge dette, kunde der ikke være Tvivl om. Men medens i Kongeriget Stavnsbaandet ophævedes ved et Paabud fra oven, saa ønskede A. P. Bernstorff, der fra 1784 til sin Dod i 1797 var ('hef for Tyske Kancelli, at Livegenskabet i Hertugdommerne maatte afskaffes gennem frivillig Tilslutning fra Ridderskabet. Dette hans Ønske var sikkert dikteret af Hensyn til de ridderskabelige Privilegier, som han ikke vilde gaa for nar.

Regeringens Eksempel blev i Aarhundredets sidste Aartier ogsaa fulgt af adskillige Godsejere. Eggers bemærker - lidt fijdsk - at hist og her viste en Godsejer sig i det mindste tilloøjelig til at gøre sig behagelig for IIoffet ved Frigivelsen af sine livegne, $\left.{ }^{2}\right)$ men foruden dette Motiv har man sikkert Lov at regne med, at ogsaa til de livegnes Herrer udbredte »den liumanere Statsfilosofis Grundsætninger« sig. Om Frigivelsen i 1786 af de livegne paa Godset $\mathrm{E} \mathbf{k}$ h of i Dänischwold findes der en samtidig udforlig Skildring, ${ }^{3}$ ) hvoraf jeg skal anføre lidt. Ekhof ejedes da af Grev Conrad Holck, velkendt eller mindre vel kendt som Deltager og Anforer $i$ den vilde Lystighed ved Hoffet i Christian VII.s forste Regeringsaar. Ved Reformerne paa Ekhof viste han sig imidlertid over for sine Bonder som en zgte "Menneskeven«, for at tale Tidens Sprog. Han lige saa lidt som hans fortræfelige Gemalinde kunde

1) Toher die wahren Quellen des Nationalwohlstandes, Freiheit, Volksmenge, Fleiss.... S. 26 .

2) Iet skand. Littematurselsk. Skr. 180). I. S. 500.

3) Schleswig-Holstein. Provinzialberichte. 178\%. I. S. $30-48$. 
nogen Sinde lade være at gøre godt og at fremme Menneskelykke, saa vidt deres Indflydelse rakte! Grev Holck lod Beboerne paa. Godset faa deres Steder i Arvefæste uden Købesum, og der udfærdigedes to Slags Arvefæstekontrakter, henholdsvis for de større og for de mindre Arvefæstere. De første ansattes til at svare Afgifter baade i Penge og Naturalier, de sidste kun i Penge, og begge forpligtedes til at udføre bestemte Tjenester for Godset, nogle uden, andre mod en aftalt Betaling. Samtidig udlagdes der af Hovmarkerne Jord til hver Kaadner og Inderst, og Greven lod bygge Huse paa disse Jordlodder.

Den Dag, da den nye Indretning iværksattes, og da Bønderne fik overrakt og underskrev Arvefæstekontrakterne, var den 15. Oktober 1786 - samme Dag som Grevinde Holck holdt sin Kirkegang efter Barsel. Bønderne samledes paa Slottet, men det Øjenvidne til Begivenhederne, der har givet os den fornæunte Skildring, savnede noget af den rette Frihedsaand og Begejstring hos dem: Kunde man ikke have ventet at se dem ile med vingede Fjed til Slottet, se Længslen tindre i deres Blikke og gløde paa Kinderne og Glæden udtrykke sig i Miner og Festdragt! Men der var intet af alt dette, tværtimod havde en af Bønderne, som han om Morgenen havde talt med, meget flegmatisk sagt, at han bekymrede sig kun lidt om Forandringen, vidste ikke, om de vilde faa det bedre efter end før, men stolede paa Naadigherren! Saadanne Toner kunde ikke andet end skurre stygt $i$ en Frihedssværmers Øren. Billedet blev dog noget ændret senere hen paa Dagen, og Frihedsstemningen kom frem, maaske vel ikke helt uden Indflydelse af den gode Beværtning, da det var det sidste Høstgilde, Greven gav. Greven talte venligt med dem alle, der taltes om "Standsforandringen «, og nu og da tiltalte Greven en Bonde som "Arvefæster". Trods Beværtningen opførte alle sig pænt, som det sømmede sig for frie Mænd, og trods Festen Natten igennem saas de næste Morgen hver ved sit Arbejde. Det var at se paa dem, hævder Beretteren, at nu arbejdede de for dem selv og for deres Børn! 
I Midten af 90 'erne lykkedes det Bernstorff at faa det slesvig-holstenske Ridderskab som Stand til at tage Initiativet til frivilligt at foreslaa Ophævelsen af Livegenskabet. Der nedsattes af Ridderskabet en Kommission herom, og efter forskellige I)røftelser indgik denne i 1797 med en Forestilling til Kongen, hvori det udtaltes, at havde det tidligere stundom vaeret nødvendigt at bede Majestæeten om Opretholdelse af de adelige Godsers Privilegier, hvor meget glædeligere var det saa ikke nu at kumne nærme sig Tronen for at bringe et Offer, der var fremkaldt af Følelsen for Menneskevel og Menneskelykke.') F'lertallet af Godsejeme havde foreslaaet Livegenskabets Ophævelse inden for en Tidsfrist af $8 \mathrm{Aar}$. I slesvig fandtes paa det Tidspunkt endnu 24 Godser med Livegne trods de adskillige Godser, hvis Besiddere allerede frivilligt havde ophavet det. At Ridderskabets Forestilling fik den fornødne Paaskønnelse hos Kongen, siger sig selv. Kongen ønskede, hedder det i den kongelige Resolution, den snarlige Opnaaelse af Maalet ogvilde agte enhver, som bidrog dertil, saa meget højere.

Lovformeligt fastsloges Livegenskabets Ophrevelse først ved Forordningen af 19 . Decbr. 1804, hvori det hedder, at Livegenskabet fuldkommen og for stedse og uden nogen som helst Undtagelse ophører fra 1. Jan. 1805, og at Kontrakter, ifølge hvilke frie giver sig som livegne til andre, er ugyldige. Men foruden demne ubetingede Hævdelse af den personlige Frihed indeholdt Forordningen meget vigtige Bestemmelser, der skulde værne om de frigivnes fortsatte økonomiske Eksistens. I lenne afhang jo af den af dem dyrkede Jord, og da denne almindelig ansaas for at tilhøre Godsejeren, stod det altsaa i dennes Magt at fordrive de frigivne fra Jorden, og det Spørgsmaal laa da nær, om ikke den personlige Frihed var købt al.t for dyrt. For at sikre de frigivne bestemte nu Forordningen dels, at Godsejeren havde Pligt til Forsørgelse (Aftagt)। over for de Bønder, Kaadnere og Inderster, der ikke ved Forpagtning

1) Tyske Kanc. Forestill. 1797 Nr. 813 (Rigwarkivet). 
eller lignende forblev paa de af dem hiltil brugte Steder, og dels, at Tallet af de paa hvert adeligt Gods værende med Jord forsynede Familiesteder ikke maatte formindskes. Dette sidste var jo en vigtig Begrænsning af Godsejerens Raadighedsret over Bondejorden, en Begræensining ud fra det Synspunkt, at Statens Tarv ikke tillod en Formindskelse af de jordejende Familiers Antal. Den tidligere nævnte Eggers, der nu var Deputeret i Tyske Kancelli, udtalte bl. a. om disse Bestemmelser, at Regeringen havde at optræde som Formynder for de moralsk umyndige, der ellers udsattes for at fornærmes til deres ubodelige Skade. ${ }^{1}$ )

Naar Livegenskabets Ophævelse skildres, er der en Mand, som ikke maa glemmes, nemlig den danske Stats faktiske Hersker, K ron prins Frederik. Denne Reform var en af ham længe næret Yndlingstanke, og $\mathrm{i}$ et Brev til Tyske Kancellis Chef, I. S. Masting, skrevet to Dage før Forordningens Udstedelse, udtaler Kronprinsen, at han med megen Fornøjelse har last Forestillingen og Forordningen nom det mig stedse forhadte Livegenskabs nu fuldkomne Ophævelse«. Herved gik, som sagt, en Yudlingstanke i Opfyldelse. Reformvennerne Llandt den danske Enevældes Tjenere havde Grund til at fole sig stolte. Som Eggers skrev: "I dette Rige, hvis Forfatning saa ofte er blevet smædet af ukyndige Skribenter, hvis gode Folk saa mange Forfattere af Rejsebeskrivelser har miskendt, ha: - lette maa Historiens Annaler bevirne -- den agte Humanitet tidligere end $i$ de fleste andre Lande loftet $\sin$ Røst. $\left.\varkappa^{2}\right)$

Medens Livegenskabets lovformelige Ophævelse i Hertugdømmerne skete et godt Stykke Tid efter Stavnsbaandsløsningen i Kongeriget, saa var man i Sonderjylland i hvert Fald ikke bagefter med Hensyn til en anden af Tidens store Landboreformer, Udskiftningen af Landsbyfallesskabet. Ldskiftningen begyndte her meget tidligt ad frivillig lej,

1) Det skandin. Litteratursplsk. Skr. 1\$og. II. S. 186.

$\left.{ }^{2}\right)$ Denkwürdigkeiten aus dem Lelen des .. Grafen von Berntorff $(1800)$. S. 40. 
og straks efter Christian VII.s Tronbestigelse greb Staten ind med et Par Forordninger for at fremme Udskiftningen. At denne mødte adskillig Modstand fra Tilhængerne af det fra Fædrene nedarvede, er forstaaeligt, og jeg skal fra Tiden før Statens Indgreb nævne et Par Eksempler paa den Modstand, Reformvennerne havde at kæmpe med, og som de maatte forsøge at overvinde.

I Landsbyen $\mathrm{H} y \mathrm{gum}$ i Fros Herred var i Begyndelsen af 1760'erne 12 af de 16 Lodsejere blevet enige om Udskiftningen. De drivende Kræfter var aabenbart Herredsfogeden og Præsten. Af de 4 andre var den ene, der hørte til Gram Gods, ikke imod, men de tre ovrige vilde ikke indlade sig herpaa. Som Bevaggrunde til Modstanden anføres for den ene, der var Storbonde, Gerrighed, for de to andre pur Egensindighed. Det er Herredsfogeden, der $i$ en Erklaring nogle Aar senere navner disse mindre kønne Bevarggrunde. ${ }^{1}$ ) og samtidig hævder han for Resten, at de fleste Bonder næsten maa tvinges til det gode, medens de snart kan blive enige om det slette! Skete Udskiftningen, vilde Glæden sikkert blive stor, og han for sit Vedkommende vilde prise sin Lykke, on han kunde bringe det saa vidt at faa sin Gaards Jorder samlede.

En langvarig og haardnakket Modstand mod sine Bestrabelser for at faa udskiftet modte ogsaa $\mathrm{N}$ i c ol a $\mathrm{u}$ s $\mathrm{O}$ es $\mathrm{t}$, der i Aaret 1744 var blevet Præst i N y k i r k e i Angel, der hørte til de daværende Lyksborgske Besiddelser. Da han endelig omkring tyve Aar efter havde faaet Udskiftningen iværksat, udgav han et lille Skrift med en Redegorelse for Udskiftningens Fordele i Almindelighed og en Beskrivelse af, hvordan man var gaaet frem i Nykirke.") Skriftet var forsynet med en Fortale af hans Provst, Philip Ernst L ü ders, en ivrig Talsmand for Forbedringer paa Landbrugets Omraade og Forfatter til en umaadelig Mængde Skrifter herom. Lüders' Navn møder

1) Skrivelse 20. Aug. 1768 i Slesv. holst. Landk. Abt. 251. Nr. 37 (Rigsarkivet).

2) Oeconomische Abhandlung von dem Acker-tomsatz .... (1765). 
vi for Resten i Johan Heinrich Voss' kendte Idyl Louise, hvor den gamle Præst skænker Svigersønnen Lüder's' Skrift om Havedyrkning, da han har hørt, i hvilken ilde Tilstand Svigersonnens lige overtagne Præstegaardshave befinder sig. Da Svigermoderen ser efter, om alt er i Orden i de nygiftes Værrelse, siger hun: "Ihm zu dämpfen die U'nruh, - Will ich die Pfeif herlegen und was sonst wünschet ein Raucher; - Auch zur Belustigung noch dies Buch von Garten- und Baumzucht, -- Aufgeklappt, das der Vater dem Eidam schenkte zum Hausbuch". - Oest kunde paa Titelbladet til sin lille Bog prange uned at være Medlem af det kongelige danske Agerbrugsakademi, Provsten, den fornemmere, kunde desuden rose sig af Medlemsskab i et Par udenlandske Landbrugsselskaber.

Begge Præsterne holdt paa, at det var vel foreneligt med deres Kald som Sjælesørgere at interessere sig for deres sognebørns timelige Velfærd, og at det bestaaende Markfællesskab var højst hinderlig for denne og gav Anledning til mangfoldige Stridigheder. I mange Landsbyer, udtalte Provsten, blev Ismaels og hans Efterfølgeres Love ærede som Rettesnor for den gensidige Tænkemaade! Han sammenlignede Fællesskabet med, om f. Eks. 16 Familier boede sammen paa den Vis, at hver Familie nok havde særskilt Beboelseslejlighed, men at de alle havde fælles Køkken, Spise-, Mælkekammer osv., og at Brugen af disse skulde ske efter forudgaaende fælles Aftaler. Pastor Oest betonede, hvordan Fællesskabet holdt Fremskridt i Landbruget nede, bundet som det var i en ufornuftig Slendrians tyranniske Aag. Han anførte tillige de mange Stridigheder, som Fællesskabet fremkaldte, hvordan man pløjede af Naboens Ager, høstede noget af hans Korn, hvordan Kreaturer, der rev sig løse, trampede Naboernes Korn ned, o. s. fr.

I 1744, da Oest blev Præst i Nykirke, forefandt han Halvdelen af Pastoratets Jord indtaget i Lykker, medens den anden Halvdel laa i Landsbyens tre Marker, Øster-, Vesterog Søndermark. Han søgte at overtale Bymændene til at 
gaa ind paa en almindelig Tdskiftning og vandt ogsaa mange herfor, men med tre af dem holdt det haardt. Den ene af disse var gammel og vilde ikke høre Tale om Forslag, der paalagde ham nye Arbejder. Denne Hindring fjernedes imidlertid, da han overlod Stedet til sin Søn, der, hvad saa ofte er Tilfældet med en yngre Generation, havde andre Tanker end de gamle. Nummer 2 var fra Isse til Fod gennemtrængt af gammel Fordom. Ham vandt Pastor Oest dog dels ved at erklære sig villig til at hjælpe ham med Omkostningerne og dels ved at overbevise andre, hvis Ord gjaldi meget hos ham. Nen Nummer 3 forblev ubnjelig. Han havde ved Stedets Overtagelse givet $\sin$ Svigerfader det Løfte ikke at indvillige i nogen Forandring, og herfra lod han sig ikke rokke. Først da han flyttede til en anden Egn, og en »bedresindet“ Efterfolger kom $i$ hans Sted, blev der endelig Mulighed for Oest at virkeliggøre sin Plan, men da var der ogsaa hengaaet 18 Aar. Han synes dog ikke at have tabt noget af sin Energi, men besluttede at smede, mens Jernet var varmt, og opnaaede Fyrstens Tilladelse til Udskiftningen paa Betingelse af, at alle var enige, og at der intet foretoges til Skade for Jagten. Den sidste Betingelse bevirkede, at Markerne foreløbig ikke fik levende Hegn. I Efteraaret 1763 lykkedes det at faa Østermarken delt, og denne Deling gav Smag paa at fortsætte med de andre Marker. Det første Arbejde paa det nye Land behagede, skriver Oest, enh'ver. De Fordele, som man sporede ved de forskellige Markarbejder (Gødningskørsel, PIøjen osv.), var en lokkende Forsmag paa Udskiftningens Frugter: "Endog Synet af de kvadratiske Stykker, hvoraf hvert om Sommeren prangede med dets egen Slags Markfrugt, var behageligt«. Efter Нøsten 1764 blev derefter de to andre Marker inddragne i Delingen mellem Cajus, Titus, Sempronius osv. - med disse latinske Navne betegner Oest den lille angelske Landsbys B.moend Mads Hansen, Søren Nielsen, Gregers Madsen - eller hvad de nu har heddet.

En Skildring som Pastor Oests af Udskiftningen i Nykirke 
læses med megen Sympati. Der er $\mathbf{i}$ den intet af den tidligere nævnte Herredsfogeds haanende Bemærkninger om Bønderne, men der er tværtimod en $d y b$ Interesse for Sognebørnenes Velfærd. Det fortjener tillige at fremhæves, at Oest ogsaa var betænkt paa at skaffe Husmændene, Kaadnerne, Jord ved Udskiftningen - hellere for rigeligt end for sparsomt, skrev han. Da en yngre Reformven, Landinspektor F. W. Otte, i 1791 paa en Fodtur gennem Angel kom til Nykirke Præstegaard, traf han her endnu Oest som Præst, hvad han altsaa da havde været i Nykirke gennem næsten et halvt Hundrede Aar. ${ }^{1}$ ) Otte ofrer mange Lovord paa Oests forbilledlige Virksomhed som Landsbypræst og fortæller om, hvordan han ved Modtagelsen førtes ind $i$ et Værelse, hvor den ærværdige Olding og hans Familie var samlet i det stille Maanelys, hvor hjertelig Modtagelsen var, og hvor ugerne han ombyttede den ærværdige gamles lærerige Underholdning med Søvnen. At Underholdningen i ikke ringe Grad har drejet sig om den for Nykirke gennem saa mange Aar tilstræbte og saa lykkelig fuldførte Udskiftning, tør man vel med Grund formode.

Som tidligere nævnt greb Staten straks efter Christian VII.s Tronbestigelse direkte ind med Bestemmelser til Gunst for Udskiftningen. I 1766 udkom den første Forordning herom for Slesvig, som dog ikke fik alt for vidtrækkende Følger, to Aar senere ved Landkommissionens Oprettelse paalagdes der den udtrykkelig at fremme Udskiftningen, og i Begyndelsen af 1770 kom den Forordning, hvis Bestemmelser blev af grund-

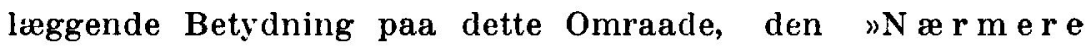
Forordning for Amter, Landskaber og Byer i Hertugdømmet Slesvig angaaende Ophævelse af Markfællesskabet og Fremmeaf Indhegningerne».

Hovedbestemmelsen i denne Forordning gik ud paa, at enhver Lodsejer for Fremtiden skulde være berettiget til at kræve

1) Otte: Bemerkungen über Angeln... (1792). 
sin Jord udskiftet af Fællesskabet ved en Opmaaling af samtlige Landsbyjorder undtagen dem, som Loven - altsaa Jydske Lov - undtog fra Opmaaling som Ornum, Kirkestuf og Særkøb. Jorden skulde saa vidt muligt udlægges til den paagældende paa eet Sted og samlet, og Omkostningerne ved Opmaalingen skulde bæres af alle Lodsejere, selv om disse vedtog at forblive $i$ det hidtidige Fællesskab. Men var det ikke en enkelt, der begærede Udskiftning, men var Halvdelen af en L.andsby, regnet efter Plovtal, enig om denne, skulde de øvrige følge deres Beslutning, og Jorderne skulde opmaales og boniteres og senere fordeles. Fordelingen var som Regel at foretage efter dẹn paa hver Egn brugelige »Proportion«, d. v. s. efter Ottinger, Mark Guld, Fjerdedele og Plovtal. Endvidere fastsatte Forordningen, hvad Hjælp der var at yde til Udflytterne af de i Landsbyen tilbageblivende Bønder, og der gaves indgaaende Regler for, hvorledes Kaadnere og Inderster skulde have Jord tillagt, naar Fællesskabet ophørte.

Forordningen af 1770 afgav i det store og hele Rammerne for den følgende Tids Udskiftningsbevægelse, selv om en og anden yderligere Bestemmelse kom til. Vigtigst var det, at man i 1786 gik over til at lade den faktiske Jordbesiddelse vere Delingsnorm i Stedet for Ejendommenes Ansæitelse i Ottinger, Mark Guld osv. Bestemmelsen om dette sidste havde naturligt nok ikke vakt Tilfredshed hos de Jordbesiddere, som i Tidens Løb havde erhvervet sig et større Jordtilliggende, end deres Ejendomme var ansat til, og den havde derfor virket som en Hindring for Udskiftningens Fremme. Samtidig med, at man i 1786 gjorde den faktiske Jordbesiddelse til Delingsnorm, foretog man imidlertid ogsaa en Regulering af Afgifterne i Forhold til denne.

Paa de forskellige Egne var det til meget forskellig Tid, at der blev udskiftet, og det var ikke for et godt Stykke ind i det 19. Aarhundrede, at man kan betragte Udskiftningen som i alt væsentligt tilendebragt. Paa Aarø i Haderslev Amt skete Ldskiftningen saaledes først efter 1825, og Initiativet hertil 
kom ikke fra Øboerne, der holdt fast ved det overleverede, men fra en mere letbevægelig Sundevedbo, der ved Egteskab var kommet i Besiddelse af en af Gaardene. ${ }^{1}$ ) - Da Forordningen 1770 ikke gjaldt for de adelige Godser, kom Spørgsmaalet om Fællesskabets Ophævelse her til at bero paa det frivillige Initiativ; til Gengæld var I'dskiftningen lettere at gennemføre, naar den kun afhang af en enkelt Mands, Godsejerens Vilje. Den skete som Regel i Forbindelse med andre Reformer som Udparcellering, Livegenskabets Ophævelse o. a., og stort set foretoges den nok noget senere end Udskiftningen $i$ Amterne.

Om Jordernes Opmaaling, Bonitering og Fordeling foreligger der mange, sikkert berettigede Klager. I Aabenraa Amt hørte saaledes Landsbyen Kassø (Hjordkær S.) til de første, der udskiftedes; det skete allerede 1766. Men om denne Udskiftning, hvorover der senere hverken lod sig fremskaffe Kort eller Forretning, hedder det, at hverken Embedsmænd, Landmaaler eller Sandemænd havde haft ringeste Idé om en Fordeling. ${ }^{2}$ ) Undersaatterne havde selv udført Forretningen, og Inan havde været glade, blot en Fordeling tilvejebragtes, den være, som den være vilde. - I Tumbøl hævdes Udskiftningen, der foregik i Begyndelsen af 70'erne, at være udført paa mesterlig Maade, men der havde ogsaa Læreren, der udførte den, Bistand af et helt Regnegeni, den af Nikolaj Andersen biograferede matematikkyndige Bonde, Jørgen Hansen, kaldet »klog Jør'n « eller "e reggenmester i Tumbøl «. ${ }^{3}$ ) Han var dog dengang en Dreng paa 13 Aar, men Læreren stolede trygt paa sine Beregningers Nøjagtighed, naar de stemte med Elevens. Et saadiant Regnegeni kunde nu ganske vist ikke ethvert Sogn prale af at eje, men som Udskiftningsarbejdet skred frem, maa i hvert Fald selve Begyndelsesvanskelighederue antages for at

1) Jahrbücher f. d. Landeskunde der Herzogthümer Schlesw., Holst. u. Lauenh. I. S. 233 ff.

${ }^{2}$ ) Slesv. Holst. Landkomm. Al,t. 251. Nr. 52 (Rigsarkivet).

3) Sønderj. Aarb. 1909. S. 79 ff. 
være overvundne. I Nøjagtighed har den sønderjydske Udskiftning dog nok $i$ det hele staaet tilbage for den kongerigske. - Man kan tænke sig, at Jordernes Fordeling i høj Grad har vakt Røre i Bymændenes Sind, og det var ikke helt grebet ud af Luften, naar det $i$ en Klage over Udskiftningen fra Lysabild siges, at $i$ disse Dage tænker den ene Nabo kun paa, hvordan han kan komme den anden til Livs. $\left.{ }^{1}\right)$ Megen ('vilje er der sikkert ogsaa opstaaet $i$. deres Sind, som den skæbne ramte at flytte ud fra Landsbyen ud paa Markerne. Datidens Bønder, siger P. Lauridsen, holdt kun af de Marker, hvorfra de kunde høre Byhanerne gale. $\left.{ }^{2}\right)$ Den ideelle Udskiftning, der vilde have været nært knyttet til en omfattende Udflytning, naaedes da heller kun de allerfarreste Steder.

Som Led i den store Landboreformvirksomhed, der udøvedes, maa ogsaa anføres Kronens Iver for at fremme Overgangen fra Fæste til Selvejend om. Ved en Forordning i 1766 var Karakteren af Kronens Fæstere som Arvefæstere iøvrigt blevet lovformeligt fastslaaet. Endvidere arbejdedes der paa at simplificere Afgiftssystemet ved at reducere de talrige forskellige Afgifter til en enkelt Sum, og der udstedtes betydningsfulde Bestemmelser angaaende Arvegangen ved Bondegods og angaaende Spørgsmaalet om Bøndergaardes Deling. En Forordning i 1784 skred saaledes ind mod den overhaandtagende Tilbøjelighed til at udstykke Gaardene og fastslog, at Gaarde som Regel ikke maatte deles i mindre Dele end Kvartgaarde.

Landboreformernes Tidsalder prægedes som bekendt tillige af meget gunstige okonomiske konjunkturer, stærkt stigende Priser paa Landbrugsprodukter $i$ 'Aarhundredets sidste Tiaar, og ogsaa af betydelige Fremskridt i s elve Landbrug sbedriften; jeg skal kun nævne Indførelsen af Kløver- og Kartoffelavl og den begyndende Mergling. Det er næppe til at undres over, at Reformerne og Fremskridtene

1) Jørgen Hansen: Die Flurverfassung der Dörfer auf der Insel Alsen im 17. u. 18. Jahrh. (1914). S. 43.

$\left.{ }^{2}\right)$ Sønderj. Aarb. 1889. S. 113. 
steg Tiden lidt til Hovedet. Man møder ogsaa i Datiden mange ldslag af Troen paa, at nu kunde Hjulet ikke mere drejes tilhage, men vilde stadig rulle fremad. I en Omtale fra 1792 i det kendte Tidsskrift "Schleswig-holsteinische Provinzialberichte" af Befolkningen i Sundeved hedder det saaledes (2. Bd. S. 211), at tidligere dyrkede Bonden sin Jord det ene Aar efter det andet uden Eftertanke og Iagttagelse, følgende sine Forfædre næsten $i$ alt. Høsten var sparsom, og $i$ fattige Kaar levede han og hans Familie. $\mathrm{Nu}$ er han som nyfødt, som foriedlet ligesom hans Jord; han "er nu en forstandig Husbond, iagttager med Fiftertanke, samler Erfaringer og ved at anvende dem, forskrækkes ikke mere for nogen okonomisk Forbedring, lærer stedse mere og vil fremtidig aldrig gaa tilbage, men forhaabentlig stedse videre fremad. Hans Velstand oges for hvert Aar, og med den hans Livs moralske Lykke, og begge vil stadig rokse med umaalelige Fremskridt«.

En saa optimistisk og historisk lidet begrundet Fremskridtstro skulde den folgende Tidsalder nu ganske vist ikke retfærdiggøre. Tiden som Lykken vendes som Bladet i Skoven. Onde Aar skifter med gode, og paa den straalende Reformtid fulgte Krig og Krise. Paa mange af Oplysnings- og Reformtidens mere overfladiske Tilhængere kunde Tidernes Skiften ikke andet end virke dybt desillusionerende. Hvor tiltalende virker det da ikke at se en af Reformtidens bedste Mænd, C $h \mathrm{r}$. Ditl. Fr. Reventlow, selv midt i Krisetiden og paa sine gamle Dage fastholde baade Stoltheden over det betydningsfulde Reformværk, til hvilket han selv havde bidraget saa kraftigt, og Haabet om, at Landbrugets Trængsler var af forbigaaende Art og skulde kunne overvindes ved Flid og Sparsommelighed og ændrede Konjunkturer. Disse Betragtninger møder vi i et udførligt Brev fra 1823 fra den gamle Greve til hans Bønder paa Sandbjærg i Sundeved, der under Tidens Tryk havde søgt ham om Hjælp.") Det er et Brev, hvori han taler som en Fader til sine Børn, og som han ender med de

1) Sunderj. Aarb. 1928. S. 290 ff. 
smukke Ord: "Jeg ønsker hjerteligt, at Gud endnu i min høje Alder vil lade mig opleve den Glæde at kunne gøre vel mod Eder, og at jeg endnu maa se Eders Velstand igen at forøges og Eder selv glade over den Velsignelse, Gud skænker Eder«. Og skønt Reventlow, der døde i 1827, ikke selv kom til at opleve, at Konjunkturerne stærkt ændredes, skulde den følgende Tid ikke gøre hans Ord til Skamme, og Landbrugets senere saa rige Udvikling skulde fuldt begrunde de storstilede Mindefester, hvormed vi i Danmark har fejret de store Landboreformers Tid. 